\title{
Transaction Costs (Tcs) Framework to Understand the Concerns of Building Energy Efficiency (BEE) Investment in Hong Kong
}

\section{Queena K Qian ${ }^{1 *}$, Steffen Lehmann ${ }^{2}$, Abd Ghani Bin Khalid ${ }^{3}$ and Edwin HW Chan ${ }^{4}$}

${ }^{1}$ Endeavour Australia Cheung Kong Fellow, Center for Sustainable Design and Behaviour (sd+b), University of South Australia, Australia ${ }^{2}$ Professor of Sustainable Design and Behaviour, School of Art, Architecture and Design Director, Zero Waste Research Centre, The University of South Australia, Australia

${ }^{3}$ Professor, Faculty of Built Environment, Universiti Teknologi Malaysia, Malaysia

${ }^{4}$ Professor, Building and Real Estate Department, The Hong Kong Polytechnic University, Hong Kong S.A.R., China

\begin{abstract}
Factors, such as split incentive, information asymmetry, opportunistic behavior, ill-informed users, and institutional transitions, etc., incur different levels of Transaction costs (TCs) and affect the stakeholders' willingness to take part in building energy efficiency (BEE). A better understanding of the nature and structure of TCs is essential to improve the market mechanisms for BEE investment. It covers three dimensions of TCs: specific investment, frequency and uncertainty. The paper provides a framework to understand BEE barriers in general and the TCs concerns of stakeholders in particular. In-depth interviews questions are designed to be conducted with the real estate representatives and architects, using a case of Hong Kong, where real estate developers are chosen to be the study object as they are the initiative and dominate force. The study focuses on how to smooth BEE transactions and lessen TCs involved. It indicates that TCs are the key factors impeding BEE market penetration, and will provide references to design a governance structure as well as to design policy packages to promote BEE.
\end{abstract}

Keywords: Transaction costs (TCs), Building Energy Efficiency (BEE), Real estate developer, Hong Kong

\section{Introduction}

Buildings account for $40 \%$ of global energy consumption and nearly one-third of global $\mathrm{CO}_{2}$ emissions Levine et al. [1]. New buildings that are energy-inefficient are being built every day, and millions of today's inefficient buildings will remain standing in 2050 [2]. Moreover, the energy usage of buildings is growing rapidly as more people move into modern homes and acquire amenities such as heating, cooling, and refrigeration. Large and attractive opportunities exist to reduce buildings' energy use at lower costs and higher returns than in other sectors. Compared to developed economies, developing countries in general lack the incentive and technical knowhow to pursue sustainability [3]. There is an urgent call for the developing countries to raise their awareness and contribute their efforts on BEE development so as to combat the climate change and address the environmental concerns [4].

Up to $50 \%$ of all energy is consumed by buildings, including the development of materials, construction, and operation. In Hong Kong, for example, buildings consume over half of all energy and about $89 \%$ of electricity, mainly for air-conditioning, which is the source of roughly $17 \%$ of all Hong Kong's greenhouse gas emissions [5-7]. In practice, improving BEE is complicated due to the many parties and factors involved: the government, the market, the endusers, many practitioners, a range of technologies, and a variety of cultures. It would be helpful for governments to know how to oversee BEE development most efficiently. BEE studies, though complicated, are necessary for improving energy efficiency and must involve more than just improving technology. Reports $[2,8]$ show that with currently available technology, the energy-efficiency level could be increased by $40 \%$, yet this does not happen. There must be some underlying reasons that call for the attention and collaboration among the key players of governing institutions, based on multi-disciplinary studies that consider economics, politics, society, technology, and so forth.

Economic theories suggest that market structure and performance is determined by the ease of entry to and exit from a market [9]. Chiang found that the institutional environment in Hong Kong led to the market concentration of the construction industry [10]. Building contractors compete intensely over cost reductions rather than technology improvements. According to the Hong Kong Consumer Council's study, the local property development market was also highly concentrated [11]. It is still true that only the large developers with superior financial resources can remain active in the sector. Under such market situations, the key market players have little incentive to venture into the new business of green building. Compared with conventional building, the entry barrier to the BEE market is higher because of the new information, expertise, new technology, and financial risk involved. If there is asymmetric information about quality standards or mandatory requirements that are not imposed on the market, the opportunistic behavior of most market players may make them continue to produce conventional buildings [12].

From the new institutional economics perspective, when Transaction Costs (TCs) are too large, they inhibit exchange, production, and economic growth. The functioning of TCs under alternative institutional arrangements is also crucial to the workings of markets [13-17]. From the transaction cost economics, energy efficiency is a coordination and incentive problem rather than one of utility maximization [18]. This view also emphasizes that policy

*Corresponding author: Queena K Qian, Endeavour Australia Cheung Kong Fellow, Center for Sustainable Design and Behaviour (sd+b), University of South Australia, Australia, Tel: 85256127050; Fax: 85223623979; E-mail: kun.qian@fulbrightmail.org

Received December 04, 2013; Accepted February 12, 2014; Published February 19, 2014

Citation: Qian QK, Lehmann S, Bin Khalid AG, Chan EHW (2014) Transaction Costs (Tcs) Framework to Understand the Concerns of Building Energy Efficiency (BEE) Investment in Hong Kong. Int J Waste Resources 4: 135. doi: 10.4172/2252 5211.1000135

Copyright: (C) 2014 Qian QK, et al. This is an open-access article distributed unde the terms of the Creative Commons Attribution License, which permits unrestricted use, distribution, and reproduction in any medium, provided the original author and source are credited. 
interventions and different institutional structures may lower TCs and provide net social benefits $[8,18,19]$. The situation calls for a thorough study focusing on how to smooth transactions for market stakeholders in energy-efficient development, with the aim of lessening the TCs involved in BEE transactions.

Figure 1 illustrates the key issues of this research for which a critical review of the literature is provided to develop a clear understanding of how they relate to one another. The consolidated issues are summarized to help develop the research questions and propositions.

This research mainly focuses on how to smooth transactions among the market stakeholders in energy efficiency development in order to realize the energy-saving target. The study does not focus on any particular type of building technology, but rather on how to marketize energy-efficient residential buildings to be more acceptable to market stakeholders. It is to lessen the TCs due to the barriers to BEE and to propose policy packages accordingly. Its intention is to identify key areas where policy initiatives can help address the market's needs for BEE with follow-up empirical study.

\section{Literature Review}

\section{TCs approach}

"Without the concept of transaction costs, which is largely absent from current economic theory, it is my contention that it is impossible to understand the working of the economic system, to analyze many of its problems in a useful way, or to have a basis for determining policy" [20].

Transaction costs, in Coase's original formulation, refer to "the cost of using the price mechanism" or "the cost of carrying out a transaction by means of an exchange on the open market" [21,22]. In Demsetz's study, "TCs may be defined as the cost of exchanging ownership titles" [23]. Gordon consolidated definition of TCs as the expense of organizing and participating in a market or implementing a government policy is the definition used in this study [24]. A number of transaction-cost issues arise with respect to the development and implementation of BEE incentive schemes. Adapting this definition is in line with the work of other authors who treat TCs and administrative costs as essentially interchangeable terms [25]. As Coase explains, "In order to carry out a market transaction, it is necessary to discover who it is that one wishes to deal with, to inform people that one wishes to deal and on what terms, to conduct negotiations leading up to a bargain, to draw up the contract, to undertake the inspection needed to make sure that the terms of the contract are being observed, and so on" [22]. Thus, there is reason to consider changing institutions, formal

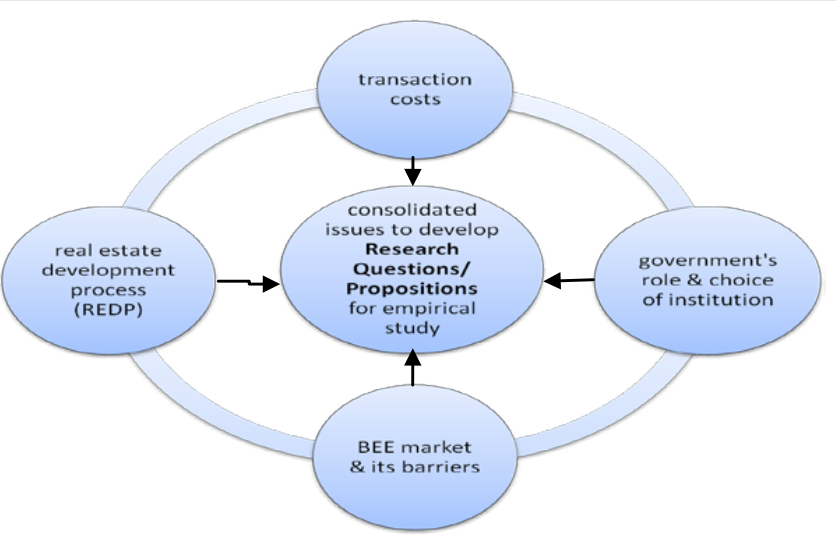

Figure 1: Five key research subjects and their interrelations. and informal rules and their enforcement arrangements, to the extent that these influence the nature of transactions and thus their costs.

Transaction cost economics (TCE) argues that markets and organizations provide alternative means of organizing economic activities and that the choice between them depends upon a number of factors, including the relative magnitude of TCs $[26,27]$. In common with orthodox economic theory, TCE explains the behavior of individuals rather than social structures and assumes these individuals to be rational actors in that they seek out opportunities to improve economic efficiency. This research applies TCE to study the underlying reasons why the market is reluctant to accept BEE by choice. The findings help establish the study's discussion on how to choose a particular governance structure to solve the existing problem.

In empirical studies, a direct measurement of TCs is simply the economic value of resources used in locating trading partners and executing transactions. Another common measurement of TCs is the difference between the prices paid by the buyers and received by the sellers. Some studies focus more on secondary costs than on direct costs per se. For example, Williamson Ian TCE is primarily interested in the secondary costs of negotiation and enforcement. Some are concerned with the cost of government regulations imposed on market entry and transactions, which either reduces the size of the market or eliminates the market altogether. In this study, the key TCA independent variables for measuring the preference of developers' for BEE investment are asset specificity (or specific investment), uncertainty (economic, market and policy uncertainty), and frequency. Asset specificity refers to durable investments that are undertaken in support of particular transactions. These specific investments represent sunk costs that have a much lower value outside of these particular transactions [27]. Uncertainty refers to three aspects: economic uncertainty, market uncertainty and policy uncertainty. Frequency refers to how often the buyers make purchases in the market [27]. Figure 2 is a TCA Model developed for this study to help understand developers' preferences for BEE investment with the consideration of TCs. Three measurement indicators for TCs items in this study are money, time, and worry. Propositions will be developed, and a set of interviews will be conducted with real estate developers and their representatives to determine the importance of TCs.

\section{BEE and its barriers}

With socioeconomic progress, more market stakeholders are getting involved in the building sector and are dedicated to their own business interests. Real estate developers intend to do no more than

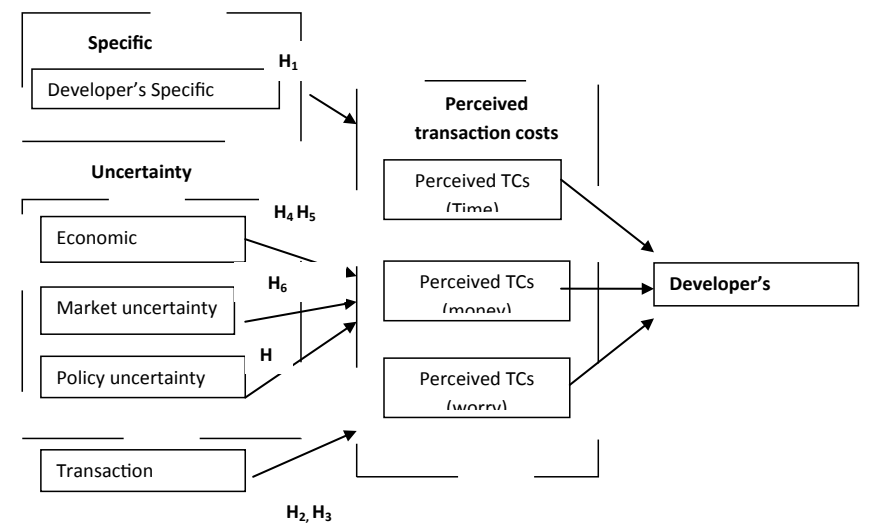

Figure 2: TCA model for real estate developers' preference on BEE investment (by the authors). 
obey the basic requirements of the law and regulatory policies to minimize the increasing costs engendered by the extra work entailed by mandatory energy regulations. Contractors also want to avoid these extra tasks, because they require special expertise and specialized equipment that they do not typically possess. Manufacturers of BEE products want regulations to be still stricter to create greater demand. Building-design institutes will not be greatly influenced by the new policies but are apt to succumb to the demands of developers because of the nature of their relationship with them. However, these interests have not yet been fully expressed by the stakeholders themselves. These conflicting interests are the main source of the risks of and barriers to BEE development.

The number of barriers is enormous - according to some estimates, they are higher in the building sector than in any other sectors $[8,28]$. In this context, a barrier refers to a mechanism that inhibits decisions or behavior that appear to be both energy and economic efficient. In particular, barriers are claimed to prevent investment in costeffective energy-efficient technologies [29]. The terms "barrier" and "market barrier" were introduced by researchers using engineeringeconomic models to study the technical and economic potential for energy efficiency. Often little interest in investments with high rates of return led to postulate that such BEE investments were inhibited by various barriers. This study has developed a framework for analyzing BEE barriers and TCs incurred based on earlier work [29,30-32]. The interview questions for the empirical study are designed based on this literature review framework (Figure 3).

\section{Barriers relating to the BEE market (Developers and End-} Users) and government's role

This study focuses on two main market players involved with energy efficient buildings - the real estate developers and the end-users, who are at the two ends of the delivery of energy-efficient buildings. It makes sense to believe that these two players are so interrelated in the market that any concerns that hinder them from investing in BEE will eventually keep the transaction from happening. Therefore, this part of the analysis is to determine how their interactions affect their willingness to invest.

Promoting BEE requires that government and all parties in the market work together. By and large, the government agencies concerned with energy efficiency end up confining themselves to providing publicity and information. The government needs to play the role of a moderator to make it convenient for the market to embrace BEE. The growth of the BEE market requires a politically friendly environment with the appropriate combination of government intervention and flexibility; it also needs a well-designed institutional structure to encourage investment and change the business culture. The government's role is mainly to set out a good foundation (the wellorganized institution) and a clear domain (clear of constraints, but also some flexibility) for the BEE market stakeholders.

\section{The hypotheses and the interview questions from BEE barriers- an overview}

Design of the interview question was based on the discussions on BEE barriers, to address three major theoretical dimensions of TCs: specific investment, frequency, and uncertainty. Seven hypotheses regarding these three aspects were developed, and related open questions about the interviewees' opinions were designed to test each of them (Table 1). Table 1 summarizes the barriers discussed in literature that the authors take reference to develop the hypotheses for empirical study. The hypotheses and the interview questions were developed based on the literature review and pilot interview with a few experts in industry and academia. The relations between the three dimensions,

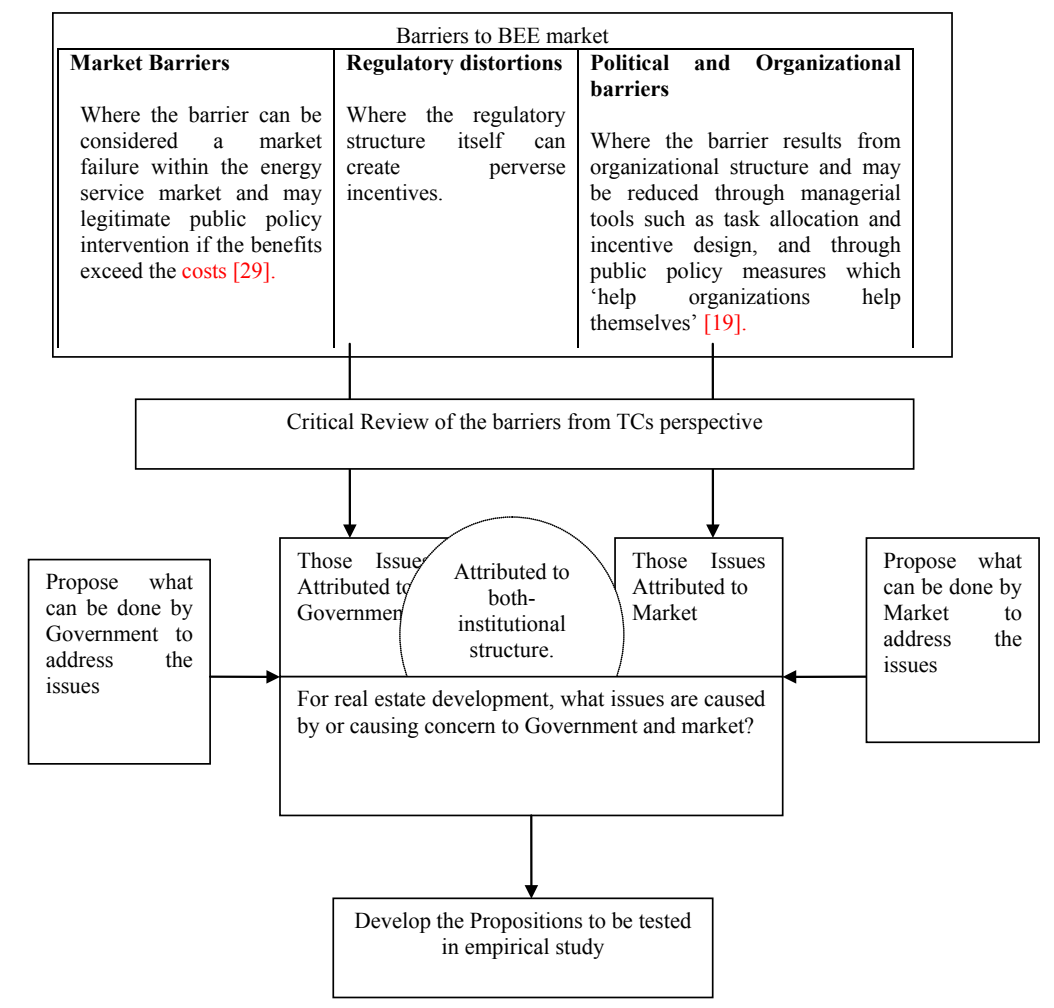

Figure 3: Literature review Framework for BEE market barriers. 


\begin{tabular}{|c|c|c|}
\hline Barriers & Common Claims & $\begin{array}{c}\text { TCs considerations of BEE- developed to } \\
\text { Hypotheses }\end{array}$ \\
\hline Risk aversion & $\begin{array}{l}\text { - BEE investment represents a higher technical or financial risk. The business \& market } \\
\text { uncertainty encourages short time capital return. } \\
\text { To replace familiar technologies and partnerships with new but more efficient ones is } \\
\text { difficult due to risks, including economic fluctuations, policy instability, possible delay, } \\
\text { and litigation, which should average out across the entire society and yield a positive } \\
\text { economic return. }\end{array}$ & \multirow{6}{*}{ 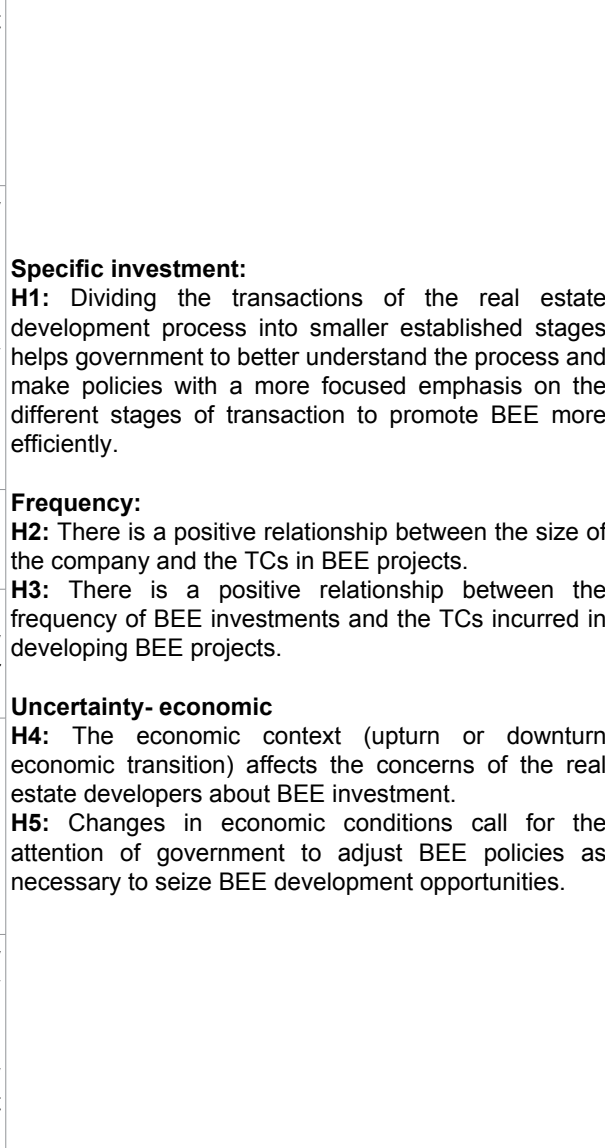 } \\
\hline $\begin{array}{l}\text { Hidden costs and } \\
\text { benefit }\end{array}$ & $\begin{array}{l}\text { - BEE potential may be overestimated by failing to account for the reduction in utility } \\
\text { associated with BEE technologies and other additional costs. } \\
\text { - The hidden costs and benefits are not captured directly in financial flows, including } \\
\text { costs associated with securing the energy efficient solution and risks associated with } \\
\text { the replacement technology. } \\
\text { - TCs are often high due to the fragmented structure of the building sector with its many } \\
\text { small owners and agents. } \\
\text { - New technologies may not be compatible with existing sockets. } \\
\text { improved health, are often ignored. }\end{array}$ & \\
\hline Imperfect information & $\begin{array}{l}\text { - Lack of information about the possibilities and techniques for and potential of energy- } \\
\text { efficient solutions is a major barrier, especially in developing countries. } \\
\text { - TCs of information acquisition may be high due to quality and credibility. }\end{array}$ & \\
\hline Negative externality & $\begin{array}{l}\text { - Non-BEE buildings consume more energy and release more carbon emissions, } \\
\text { which are the negative externalities and need to be taken into account and be fairly } \\
\text { apportioned to keep the end-users and developers from losing the motivation to further } \\
\text { invest in BEE. }\end{array}$ & \\
\hline Access to capital & $\begin{array}{l}\text { - BEE investments may be avoided if market stakeholders have insufficient capital } \\
\text { through internal funds, and has difficulty in raising additional funds, due to internal } \\
\text { capital budgeting procedures, investment appraisal rules and the short-term/instable } \\
\text { incentives. } \\
\text { - Higher capital costs raise the uncertainty and opportunity costs to the stakeholders, } \\
\text { especially if the investment is financed by a mortgage or other loan. Besides, BEE } \\
\text { investment would normally require a longer payback period, which increases business risk. }\end{array}$ & \\
\hline Public goods & $\begin{array}{l}\text { - BEE would prevent society from consuming extra energy and releasing unnecessary } \\
\text { pollution, and have a collective effect society as a whole would benefit from, and many } \\
\text { would benefit as free riders. BEE itself creates a lack of interest in itself as a business } \\
\text { initiative. } \\
\text { - The availability of BEE information is also a public good. The public requires a large flow } \\
\text { of extra information to have confidence in breaking its routine to invest in BEE. Market } \\
\text { stakeholders need to have public and transparent information about technology. }\end{array}$ & \\
\hline Bounded & $\begin{array}{l}\text { - Owing to constraints on time, cost, and the ability to process information, imitated } \\
\text { knowledge of the stakeholders on BEE investment, they either have an irrationally high } \\
\text { expectation for the BEE investment }\end{array}$ & \multirow{3}{*}{$\begin{array}{l}\text { Uncertainty- market } \\
\text { H6: The end-users' variable expectations about BEE } \\
\text { increase market uncertainty to the developers (e.g.., } \\
\text { they may misinterpret a focused group as the end-users } \\
\text { of their final products). }\end{array}$} \\
\hline rationality & $\begin{array}{l}\text { - Return and/or payback period or more interested in pursuing other short-term } \\
\text { alternatives or to neglect the small cost savings from the energy efficiency improvement. } \\
\text { - Changing behavior or lifestyles is very difficult. A lack of awareness and information } \\
\text { about the opportunities and low costs of energy savings are a related problem. Energy } \\
\text { subsidies are considered to be one of the most important BEE barriers in developing } \\
\text { countries. }\end{array}$ & \\
\hline Split incentives & $\begin{array}{l}\text { - The cost and benefit of BEE is bear by different parties and difficult to appropriate } \\
\text { among the investors. } \\
\text { - The developers are reluctant to invest unless someone is going to pay for it. Similarly, } \\
\text { utilities have no direct interest in measures for reducing their clients' energy use. }\end{array}$ & \\
\hline Regulatory distortions & $\begin{array}{l}\text { - The regulatory structure can create perverse incentives in form of regulatory bias, } \\
\text { under-priced energy, building codes, and subsidies to established energy technologies. } \\
\text { The building codes are not updated in a timely fashion, which inhibits technology } \\
\text { innovation and interferes with efficient construction; inconsistency confuses the market } \\
\text { and creates obstacles to achieve economies-of-scale for BEE. }\end{array}$ & \multirow{2}{*}{$\begin{array}{l}\text { Uncertainty- policy } \\
\text { H7: The earlier the stage of BEE policy implementation, } \\
\text { the greater the real estate developers' concern about } \\
\text { TCs. }\end{array}$} \\
\hline $\begin{array}{l}\text { Political and } \\
\text { Organizational } \\
\text { barriers }\end{array}$ & $\begin{array}{l}\text { - A lack of government involvement in promoting BEE due to inadequate enforcement } \\
\text { structures and institutions; inappropriate government intervention that distorts business } \\
\text { activities; the inflexibility of local governments; an insufficient number of qualified } \\
\text { personnel; the lack of a long-term energy conservation mechanism; a lack of credible } \\
\text { third-party agencies; the slow pace of institutional reform; worries about social stability; } \\
\text { policies or programs that are incompatible with one another; resistance from interested } \\
\text { parties; legal \& urban-planning constraints; weak investment culture; weak managerial } \\
\text { supervision of manpower \& organization; problems with multi-institutional collaboration } \\
\text { \& coordination; local governments' resistance to change; and corruption. }\end{array}$ & \\
\hline
\end{tabular}

Simon [36], Stern and Aronson [37], Koomey [31], Golove and Eto [19], Alam [38], Deringer [39], Shove [40], Wrestling [41], Evander [42], Sorrell [29], Chappells and Shove [43], Carbon Trust [44], Vine [45], Koeppel [8].

Table 1: Barriers to BEE and their TCs considerations to develop the hypotheses for empirical interviews. 
Citation: Qian QK, Lehmann S, Bin Khalid AG, Chan EHW (2014) Transaction Costs (Tcs) Framework to Understand the Concerns of Building Energy Efficiency (BEE) Investment in Hong Kong. Int J Waste Resources 4: 135. doi: 10.4172/2252-5211.1000135

Page 5 of 7

seven hypotheses $(\mathrm{H})$, and fifteen interview questions $(\mathrm{Q})$ are listed in Tables 2-4 below. The Remarks explain how the interview questions relate to the hypotheses.

\section{Design of the Interview Questions from the Hypotheses- In Details}

\section{Questions for Specific Investment}

Specific investment in BEE increases the workloads of developers and the resources they need, which increases their concerns as they decide whether to make a BEE investment.

Hypothesis (H1) proposes that in securing a detailed understanding of the BEE elements, such as technologies, appliances, or inputs for specific investments, it is better to break down the real estate development process, by the difficulty of retrofits (Q2), by the type of buildings (luxury or low-price), (Q3). The purpose of these questions is to determine whether the policies can be designed for a highly specific group with effective incentives for securing investments in BEE.

Q1 is to elicit the underlying reasons and the approximate limit (as percentage of the development budget) that the developers would be willing to invest in BEE without incentives from the government. The purpose is to see if the government could create a business environment conducive to BEE with any market interventions. Q4 addresses one of the most notorious features of BEE - misplaced interests - in order to understand how they affect the current situation, determine what about them concerns developers, and determine what, if any, resolution is called for by the market. These five interview questions collectively address, from different perspectives, the issues raised by Hypothesis H1. The open question format allows the interviewees to talk freely about their concerns in a wider context.

\section{Questions for frequency of BEE investment}

The frequency of BEE transactions is another dimension that affects TCs. How frequently the developers invest in BEE may affect their concerns differently. The TCs may thus change accordingly (H3).

Q7 and Q8 are the two questions that address the relationship between the level of concerns about BEE investment and the frequency of BEE transactions. The nature of this relationship may help governments design different policies to encourage investment by frequent and occasional investors by taking into account their different concerns.

The size of the company and the size of the project also affect investors' capacity to invest and, therefore, the frequency with which they do so (H2). Big companies may have different concerns and strategies than smaller ones when it comes to BEE investments (Q6). To integrate green features into bigger projects may have different impacts in terms of TCs, compared to smaller ones (Q5).

To understand how changing concerns are a function of the size of the RED company or project and the frequency of BEE investment requires knowing market segmentation according to both size and frequency. This information allows government to design and specify incentives for more focused groups.

\section{Questions for uncertainty}

Uncertainty about BEE investments is one of the general features of TCs that causes real estate developers worry. Uncertainty is examined in this study from three perspectives: economic uncertainty, market uncertainty, and policy uncertainty.

What is the impact of economic transition on the BEE development (to the developer - H4; to the government - H5)? Is it a challenge or an opportunity? How do the developers' concerns change in an economic

Q1 What are the reasons that make developers willing to invest in new BEE technology without government incentives? What price difference (\% of development cost) would be acceptable?

Uneven emphasis on incentives: What facilities/building elements are more expensive/difficult to be retrofitted, if not installed in the first place? Should they be emphasized in incentives to promote BEE investment?

Q3 For developers investing in BEE, what are the different concerns of investing in luxury buildings and in lower-priced buildings? Why?

Q4 There is misplaced benefit between the people who pay and who gain from BEE. To address this problem, would rental/selling-price differences help?

Table 2: Specific Investment - relating to $\mathrm{H} 1$.

Q5 Will the size of the project affect the developers' concerns about BEE investment?

Q6 Will the size of the RED company affect the developers' concern about BEE investment?

Q7 How does the frequency (e.g., regular, occasional, or at one-time) of developers' BEE investments affect their concerns about BEE investment?

Q8 Would the developers' concerns change if they invested in BEE projects more frequently? Why?

Table 3: Frequency: relating to $\mathrm{H} 2-\mathrm{H} 3$.

\section{Economic uncertainty}

Q9 At times of economic transition, what new challenges or opportunities arise for investments in BEE? How do shifts in the economy change the developers' major concerns (neutral, positive, or negative) and in which aspects?

Q10 When the direction of the economy shifts, how might developers integrate green features into original investments to increase market competitiveness?

Q11 What role should government play in BEE promotion (more intervention or less intervention in a recessionary economy)?

Q12 What BEE promotions or incentive could government introduce in times of economic change that would be less upsetting to the market players' normal activities?

\section{Market uncertainty}

Q13 Occupants' behavioral differences may lead developers to produce different BEE/GB at different performance levels. What is your view?

Q14 Will concerns about social classes (different education levels, experiences, financial ability to enjoy the benefits of BEE) affect the developers' concern about BEE investment?

Policy uncertainty

Q15 Would a new incentive and a currently mature incentive affect the developers' concerns about BEE differently? In other words, encountering BEE incentives, would the developers have more concerns during the early or later stage of the implementation of the incentive? How are they different?

Table 4: Uncertainty: relating to $\mathrm{H} 4-\mathrm{H} 7$. 
downturn or upturn? What should government be alert to during such periods and how can it develop the most effective policies to promote BEE accordingly? These are the main issues that are addressed in interview questions Q9- Q12.

The market also creates many uncertainties for developers. They may be hesitant to invest in BEE due to a lack of confidence in estimations of market demand. The end-users' expectations and concerns about BEE may be better known, so that both the developers and the government could seize the opportunity to promote BEE. This brings H6 onto the horizon. Q13 and Q14 are designed to detail the behavior and concerns of the market end-users about BEE by segmenting the customers so that the real estate developers might have a more confident business strategy and so that the government can design its incentive policies to cater to more focused groups based on a better understanding of the needs and concerns of both end-users and developers.

Policy also affects uncertainty during different implementation stages. This uncertainty affects the worries and enthusiasm of the market variously, thus affecting the effectiveness of the policies themselves. The policy uncertainty is based on the assumption that the timing of the policy's introduction is a major factor in causing uncertainty for the real estate developers (H7). Q15 is designed to elicit information about how the stage at which the policy is implemented affects the real estate developer's concerns, which gives government information that lets it have market concerns in mind as it implements policy at different points in the process.

\section{Discussions on the Role and the Partnership of Government and Business in Promoting BEE}

As an authority to set up institutions and design policies, government is more able to improve its own efficiency and internal decision-making than to improve its external counterpart, the market. Government should adopt a clear national policy to improve energy efficiency through a coherent package of policy measures. Policy mechanisms alone will not work and market forces by themselves will not achieve the potential for energy efficiency. Because the spread of energy efficiency improvements cannot be left to the market, there has to be an emphasis on policy-assisted, market-oriented mechanisms for promoting energy efficiency.

To determine the most needed policies to improve BEE in a particular society requires an in-depth understanding of the expectations of the market and government. Most policymakers regard energy efficiency principally as an environmental or social issue, rather than an economic one. Hence, policies are designed with inadequate consideration of the needs of market stakeholders and not pay enough attention to the necessity that businesses accept them. Government tends to pay more attention to the environmental consequences of energy consumption, and business enterprises may care more about their technical and financial ability to make changes, their potential economic benefits, and so forth. Detailed negotiation and greater understanding between government and the market stakeholders is needed to reach a win-win outcome.

Only when both the end-users and the developers appreciate the benefits of energy efficiency building will they create a business channel for BEE products and the BEE market. Each of the barriers discussed above provides an opportunity for policies to address, but it will involve simple matches of one policy to one barrier. It will require a careful selection and combination of a set of policy instruments to overcome these existing barriers. How, then, do we choose among so many policy instruments? Economic theory, along with careful analysis of BEE barriers, provides guidance for matching policies to barriers.

\section{Follow-Up Studies: Empirical Research on BEE to Be Conducted In Hong Kong}

\section{Why is Hong Kong chosen as a case study?}

Hong Kong is a suitable choice for this study, as it is economically well-developed regions with free markets and fairly educated professionals for green building and energy efficiency. The GDP per capita at current market prices in 2007 in Hong Kong was U.S. \$41,110 (IMD World Competitiveness Yearbook, 2007). Construction as a share of total GDP has been in the range of 5-7\% in Hong Kong in recent years [33]. Harnessing solar energy through solar cells, sunshading devices, low-emissivity glass, energy-efficient air-conditioning systems, and building-space planning and orientation are common design considerations for BEE in Hong Kong. Hong Kong relies more on voluntary effort, and there are several green groups, such as the Professional Green Building Council and the Green Council, promoting the voluntary use of BEE. The HK-BEAM and other greenlabel programs are accepted assessment tools promulgated by voluntary bodies in the past decade. In recent years, the Hong Kong government has begun to take an active part in driving BEE initiatives [34,35].

\section{Why in-depth interview the real estate developers?}

In-depth interviews were conducted with the executives and architects who work in big real estate development firms in Hong Kong to solicit their views on issues regarding BEE investment. The interviewees to be selected are top managers or directors from the top 6 real estate development companies, who actively worked in major real estate development firms or architectural firms, which covered $80 \%$ of real estate activities in Hong Kong. As the decision-makings and strategic plans for the real estate development- whether BEE or not, and market expectations/ concerns to BEE, are only done by people who are senior and stay high position.

The interviews to the high profile practitioners will reflect their preference to current BEE development in practice, which directly and indirectly reflect their will if and how to achieve the BEE decision-makings, and have a very heavy weight to influence the other stakeholders in the BEE market and overall BEE promotions. Therefore, the findings of the interviews are to get the perspectives of real estate developers and to check the assumptions and findings about BEE market barriers in the literature review. It is to hope to provide a reference for designing rational policy.

\section{Conclusions}

This study develops a methodology framework of the TC theories to be tested in the real world interviews in an empirical study of Hong Kong. This study has adopted a holistic approach to studying the barriers to BEE investments and has focused on TCs in particular. It provides a review of diverse literatures, including those on building energy efficiency, TCs, and real estate development. This research has comprehensively analyzed the market barriers to BEE and TCs incurred from the perspectives of the developers. The overall methodology framework is theoretically significant with the original data from a case study in Hong Kong to bring a thorough understanding of BEE market. The results will definitely help understand the real market concerns in terms of TCs regarding BEE development. It helps the policy makers to understand when, to whom, where, and how to design the policies 
Citation: Qian QK, Lehmann S, Bin Khalid AG, Chan EHW (2014) Transaction Costs (Tcs) Framework to Understand the Concerns of Building Energy Efficiency (BEE) Investment in Hong Kong. Int J Waste Resources 4: 135. doi: 10.4172/2252-5211.1000135

that are in favor to the real need of the market. It, therefore, ensures the success of BEE implementation.

\section{Acknowledgement}

The work described in this paper was supported by joint research grant from The Hong Kong Polytechnic University, and University Technology Malaysia (UTM), Malaysia. Special thanks to the Endeavour Research Fellowship Program and Center for Sustainable Design and Behaviour $(\mathrm{sd}+\mathrm{b})$, University of South Australia for the supports.

\section{References}

1. Levine M, Urge-Vorsatz D, Blok K, Geng L, Harvey D, et al. (2007) Residential and commercial buildings. In Climate Change 2007 Mitigation Contribution of Working Group III to the Fourth Assessment Report of the Intergovernmental Panel on Climate Change 389-437.

2. WBCSD (2009) Energy Efficiency in Building: Business realities and opportunities. World Business Council for Sustainable Development.

3. Ugwu OO, Haupt TC (2007) Key performance indicators and assessment methods for infrastructure sustainability a South African construction industry perspective. Building and Environment 42: 665-680.

4. Qian QK (2012) Barriers to Building Energy Efficiency (BEE) Promotion: A Transaction Costs (TCs) perspective. The Hong Kong Polytechnic University.

5. Civil Exchange (CE) (2008) Submission on a proposal on the mandatory implementation of the building energy codes.

6. Environmental Bureau (EB) (2008) Policy and consultation papers: a proposa on the mandatory implementation of the building energy codes.

7. Chan EHW, Qian QK, Lam PTI (2009) The Market for Green Building in Developed Asian Cities the Perspectives of Building Designers. Energy Policy 37: 3061-3070.

8. Koeppel, Urge-Vorsatz D (2007) Assessment of policy instruments for reducing greenhouse gas emissions from buildings.

9. Baumol W, Panzer JC, Willig RD (1982) Contestable markets and the theory of industry. Structure Harcourt Brace Jovanovich.

10. Chiang YH, Tang BS, Leung WY (2001) Market structure of the construction industry in Hong Kong. Construction Management and Economics 19: 675-687.

11. Hong Kong Consumer Council (HKCC) (1996) How competitive is the private residential property market?

12. Akerlof G (1970) The market for lemons: quality uncertainty and the marke mechanism. Quarterly Journal of Economics 84: 488-500.

13. Cheung SNS (1998) The transaction cost paradigm Presidential Address Western Economic Association. Economic Inquiry 36: 514-521.

14. Coase RH (1988) The Firm the Market and the Law. University of Chicago Press.

15. Benham A, Benham L (1997) Property rights in transition economies: A commentary on what economists know.

16. North DC (1990) Institutions institutional change and economic performance. Cambridge and New York: Cambridge University Press.

17. North DC (1991) Institutions. Journal of Economic Perspectives 5: 97-112.

18. Levine MD, Koomey JG, McMahon JE, Sanstad AH, Hirst E (1995) Energy Efficiency Policy and Market Failures. Annual Review of Energy and the Environment 20: 535-555.

19. Golove WH, Eto JH (1996) Market barriers to energy Efficiency: a critical reappraisal of the rationale for public policies to promote energy efficiency. Energy \& Environment Division USA: 1-46.

20. Coase RH (1998) Our Challenge and Goals.

21. Coase RH (1937) The nature of the firm. Economics 4: 386-405

22. Coase RH (1961) The problem of social cost. Journal of Law and Economics 3: $1-44$.

23. Demsetz H (1968) The cost of transacting. Quarterly J of Econ 82: 33-53.
24. Gordon RL (1994) Regulation and Economic Analysis: A critique over two centuries. Topics in Regulatory Economics and Policy Series 16.

25. McCann L, Colby B, Easter KW, Kasterine A, Kuperan KV (2005) Transaction cost measurement for evaluating environmental policies. Ecological Economics 52: $527-542$.

26. Williamson OE (1979) Transaction cost economics: the governance of contractual relations. Journal of Law and Economics, 22: 233-261.

27. Williamson OE (1985) The Economic Institutes of Capitalism. New York

28. Parry ML, Canziani OF, Palutikof JP, Linden PJ, Hanson CE (2007) Climate Change: Impact Adaptation and Vulnerability. Contribution of Working Group II to the Fourth Assessment Report of the Intergovernmental Panel on Climate Change.

29. Sorrell S, O'Malley E, Schleich J, Scott S (2004) The Economics of Energy Efficiency: Barriers to Cost-Effective Investment., Edward Elgar Publishing Limited.

30. Robert GH, Carman JM (1983) Public Regulation of marketing Activity: Part Institutional Typologies of Market Failure. Journal of Macromarketing 3: 49-58.

31. Koomey JG (1990) Energy Efficiency in New Office Buildings: An Investigation of Market Failures and Corrective Policies. Energy and Resources Group Berkeley.

32. Jaff AB, Stavins RN (1994) The energy-efficiency gap What does it mean? Energy Policy 22: 804-810.

33. Raftery J, Anson M, Chiang YH, Sharma S (2004) Regional overview. The Construction Sector in Asian Economics London.

34. Chan EH (2000) Impact of major environmental legislation on property development in Hong Kong: 273-295.

35. Chan EH, Lau SS (2005) Energy conscious building design for the humid subtropical climate of Southern China Green Buildings Design: Experiences in Hong Kong and Shanghai Architecture and Technology Publisher China: 90-113.

36. Simon HA (1960) The New Science of Management Decision. Harper \& Bros New York.

37. Stern P, Aronson E (1984) Energy Use: The Human Dimension.

38. Alam M, Sathaye J, Barnes D (1998) Urban household energy use in India efficiency and policy implications. Energy Policy 26: 885-891.

39. Deringer J, lyer M, Huang YJ (2004) Transferred Just on Paper? Why Doesn't the Reality of Transferring / Adapting Energy Efficiency Codes and Standards Come Close to the Potential? ACEEE Summer Study on Energy Efficiency in Buildings.

40. Shove E (2003) Comfort, cleanliness, and convenience: the social organization of normality. Berg Publishers Oxford and New York.

41. Wrestling $H$ (2003) Performance Contracting. Summary Report from the IEA DSM Task $X$ within the IEA DSM Implementing Agreement. International Energy Agency Paris.

42. Evander AG, Sieboock, Neij L (2004) Diffusion and development of new energy technologies: lessons learned in view of renewable energy and energy efficiency end-use projects in developing countries Lund: International Institute for Industrial Environmental Economics.

43. Chappells $\mathrm{H}$, Shove $\mathrm{E}$ (2005) Debating the future of comfort: environmenta sustainability, energy consumption and the indoor environment. Building $\mathrm{Re}$ search and Information, 33: 32-40.

44. Carbon Trust (2005) The UK Climate Change Programme: Potential Evolution for Business and the Public Sector.

45. Vine $E$ (2005) An international survey of the energy service company (ESCO) industry. Energy Policy 33: 691-704.

Citation: Qian QK, Lehmann S, Bin Khalid AG, Chan EHW (2014) Transaction Costs (TCS) Framework to Understand the Concerns of Building Energy Efficiency (BEE) Investment in Hong Kong. Int J Waste Resources 4: 135. do: 10.4172/2252-5211.1000135 